\title{
KAJIAN FISIKOKIMIA DAN ORGANOLEPTIK VELVA KACANG HIJAU RASA WORTEL
}

\section{Tri Rettagung Diana, U. Yuyun Triastuti, Denta Nabila Rizki}

Program Studi Seni Kuliner Akademi Kesejahteraan Sossial Ibu Kartini Semarang, Program Studi Teknologi Pangan Universitas Diponegoro (UNDIP) Semarang, Indonesia

Email: rettagungdiana@gmail.com, yuyuntriastuti94@gmail.com, dentaa006@gmail.com

\begin{abstract}
Abstrak
Velva kacang hijau wortel merupakan salah satu jenis frozen dessert yang terbuat dari kacang hijau dan wortel, dengan pemanis madu, dan bahan tambahan air dan kulir jeruk lemon, garam dan cmc. Teknik pengolahan dibekukan dengan alat pembekuan es krim. Penelitian ini bertujuan untuk mengetahui pengaruh substitusi wortel sebagai perasa dan pewarna, yang akan mempengaruhi karakteristik fisik yaitu overrun, kemudian karakeristik kimia yaitu total padatan dan kadar serat kasar serta karakteristik hedonik velva kacang hijau rasa wortel. Penelitian ini menggunakan 4 perlakuan dan 3 kali ulangan dengan variasi konsentrasi puree wortel V0 (0\%), V1 (20\%), V2 (40\%), V3 (60\%), dan V4 (80\%) dari berat puree kacang hijau. Bahan baku yang digunakan yaitu kacang hijau, wortel air, madu, air jeruk lemon, carboxyl methyl cellulose $(\mathrm{cmc})$ dan garam. Hasil dari penelitian ini yaitu variasi penambahan konsentrasi pure wortel memberikan pengaruh yang berbeda nyata $(\mathrm{P}<0,05)$ terhadap overrun, daya leleh, total padatan serta tekstur dari velva kacang hijau rasa wortel. Substitusi puree wortel cenderung menurunkan $0,48 \%$. Perlakuan substitusi puree wortel pada yang optimal yaitu sebesar $60 \%$ karena menghasilkan overrun sebesar $16,93 \%$; daya leleh yang memenuhi kualitas mutu yaitu 15,57 menit, total padatan yang memenuhi standar sebesar 26,26\%; serta menghasilkan karakteristik hedonik yang dapat diterima dengan baik oleh konsumen.
\end{abstract}

Kata Kunci: kacang hijau; wortel; velva

\section{Abstract}

Carrot green bean velva is a type of frozen dessert made from green beans and carrots, sweetened with honey, and additional ingredients of water and lemon peel, salt and cmc. The processing technique is frozen with an ice cream freezer. This study aims to determine the effect of carrot substitution as a flavoring and coloring agent, which will affect the physical characteristics, namely overrun, then chemical characteristics, namely total solids and crude fiber content and the hedonic characteristics of velva mung bean with carrot flavor. This study used 4 treatments and 3 replications with variations in the concentration of carrot puree V0 (0\%), V1 (20\%), V2 (40\%), V3 (60\%), and V4 (80\%) by weight of mung bean puree. The raw

$\begin{array}{ll}\text { How to cite: } & \text { Diana. T.R., U. Yuyun Triastuti \& Denta Nabila Rizki (2022) Kajian Fisikokimia dan Organoleptik Velva } \\ & \text { Kacang Hijau Rasa Wortel. Syntax Literate: Jurnal Ilmiah Indonesia, 7(1). http://dx.doi.org/10.36418/ } \\ & \text { Syntax-Literate.v7i1.6030 } \\ & \text { 2548-1398 } \\ \text { E-ISSN: } & \text { Ridwan Institute }\end{array}$


materials used are green beans, carrot water, honey, lemon juice, carboxyl methyl cellulose ( $\mathrm{cmc}$ ) and salt. The results of this study were variations in the addition of carrot puree concentration had a significantly different effect $(P<0.05)$ on overrun, melting power, total solids and texture of carrot-flavored green bean velva. Carrot puree substitution tends to decrease $0.48 \%$. The optimal treatment for carrot puree substitution was $60 \%$ because it resulted in an overrun of $16.93 \%$; melting power that meets the quality quality is 15.57 minutes, the total solids that meet the standard are 26.26\%; and produce hedonic characteristics that are well received by consumers.

Keywords: green beans; carrots; velva

Received: 2021-12-20; Accepted: 2022-01-05; Published: 2022-01-15

\section{Pendahuluan}

Velva merupakan salah satu frozen dessert yang terbuat dari puree buah dengan tekstur mirip dengan es krim. Velva dikenal juga dengan nama sorbet. Produk ini terbuat dari campuran puree (bubur) buah, gula sukrosa dan bahan penstabil yang dibekukan sehingga diperoleh tekstur yang halus dan menyerupai es krim (Sommer,1947) pada (Silva, et al, 2018). Perbedaan velva dengan es krim adalah kadar lemaknya, velva sangat rendah lemak karena tidak menggunakan lemak susu. Apabila lemak dibutuhkan bisa digantikan dengan susu nabati, dengan memanfaatkan kacang hijau.

Kacang hijau selain sebagai salah satu sumber protein nabati, juga sebagai sumber serat yang baik untuk pencernaan, mengendalikan berat badan, mengurangi resiko anemia, mencegah tekanan darah tinggi, menyehatkan otak, keluhan pascamenopause, diabetes, bermanfaat untuk ibu hamil dan menyusui, serta dapat mencegah penyakit jantung (Mustakim, 2014), kacang hijau memiliki kandungan serat pangan sebesar 4,1\% per $100 \mathrm{~g}$ (Utafiyani, et al, 2018), sedangkan wortel mengandung serat 2,8 g/100 g (Azlan, 2018).

Warna oranye pada wortel merupakan pertanda kandungan karotenoidnya yang sangat tinggi. Wortel dapat dijadikan sebagai bahan baku Velva karena selain kaya nutrisi yang diperlukan tubuh, wortel juga mengandung inulin dan serat pangan yang dibutuhkan untuk pemeliharaan kesehatan khususnya saluran pencernaan. Selain itu, kandungan $\beta$ - karoten (180 SI/g) dalam wortel akan memberikan warna velva yang menarik.

Velva kacang hijau rasa wortel juga mempunyai kelebihan, yaitu tinggi protein yang berasal dari kacang hijau dan mengandung vitamin A yang berasal dari wortel. Pemakaian kacang hijau dengan substitusi sari wortel merupakan alternatif frozen dessert bergizi, yang diperuntukkan bagi kelompok vegetarian maupun untuk menu diet rendah lemak, namun juga dianjurkan untuk siapa saja yang menginginkan hidup sehat.

Keanekaragaman sayuran dan buah-buahan membuat Indonesia dikenal sebagai negara produsen tertinggi penghasil sayuran dan buah-buahan (Zurriyati \& Dahono, 
2016), sehingga kacang hijau dan wortel sangat berpotensi sebagai bahan alternatif dalam memproduksi pangan fungsional (Hayashi, et al, 2001).

Sifat fungsional dari kacang hijau, wortel, jeruk lemon, dan madu, yang terkandung didalam velva kacang hijau rasa wortel, diharapkan dapat menjadi produk yang lezat, menarik, dan bergizi, serta dapat memberikan manfaat bagi kesehatan. sehingga dapat digemari masyarakat tentunya. Pengolahan kacang hijau dan wortel menjadi velva merupakan salah satu diversifikasi produk pangan dan juga merupakan alternatif produk dessert frozen yang dapat menghasilkan nilai ekonomis yang tinggi serta dapat berperan sebagai pangan fungsional untuk diet rendah lemak.

\section{Metode Penelitian}

Penelitian dilaksanakan pada bulan Juni-November 2021 di Laboratorium Seni Kuliner, Akademi Kesejahteraan Sosial Ibu Kartini Semaran. Bahan yang digunakan pada penelitian ini yaitu kacang hijau, wortel, madu, air, jeruk lemon, garam dan Carboxy Methyl Cellulose (cmc), $\mathrm{H} 2 \mathrm{SO} 4$ 0,3 N, aquadest, $\mathrm{NaOH}$ 1,5 N, dan aceton. Alat yang digunakan meliputi ice cream maker, blender, mixer, refrigerator, freezer, cawan porselin, oven, labu erlenmeyer $300 \mathrm{ml}$, kertas saring, furnace, desikator, penjepit, timbangan analitik, panci, kompor, gelas ukur, gelas beaker, plastic wrap, sendok, toples, saringan 60 mesh, baskom,dan cup plastik.

Pengukuran overrun pengembangan volume velva kacang hijau rasa wortel dianalisa dengan cara yaitu adonan velva kacang hijau rasa wortel, sebelum dan sesudah diproses dalam ice cream maker diukur beratnya, dengan volume yang sama menggunakan gelas beaker, kemudian hasil yang diperoleh dikalkulasi dalam rumus $\%$ overrun $=[($ volume of product-volume of mix) $/$ volume of mix $] \times 100$ (Goff \& Hartel, 2013).

Pengukuran daya leleh velva kacang hijau rasa wortel dinilai secara kualitatif, dengan mengamati proses lelehan velva. Langkah pengamatan dimulai dengan mempersiapkan velva kacang hijau rasa wortel di cawan petri sebanyak $10 \mathrm{~g}$. Selanjutnya diletakkan pada ruang yang bersih, dan cukup terang, serta bersuhu ruang sekitar $20{ }^{\circ} \mathrm{C}\left(70{ }^{\circ} \mathrm{F}\right)$. Velva kacang hijau rasa wortel ditunggu sampai meleleh dengan waktu pencairan dalam waktu 15-20 menit (Goff \& P, 2001).

Total padatan velva kacang hijau rasa wortel untuk penentuannya dilakukan penghitungan, dengan langkanya pertama menyiapkan cawan porselin yang bersih, dan dikeringkan dalam oven dengan suhu $105^{\circ}-110^{\circ} \mathrm{C}$ selama 1 jam. Kemudian didinginkan dalam desikator selama 15 menit dan ditimbang beratnya. Sampel velva kacang hijau rasa wortel diletakkan dalam cawan porselin lalu ditimbang beratnya. Sampel dalam cawan porselin kemudian dikeringkan dalam oven dengan suhu $105^{\circ}-110^{\circ} \mathrm{C}$ selama 24 jam kemudian didinginkan dalam desikator selama 15 menit dan ditimbang kembali beratnya. Penimbangan ini dilakukan berulang hingga diperoleh berat yang konstan. Kadar air dihitung dengan membagi selisih berat awal dan akhir sampel (setelah dikeringkan) dengan berat awal sampel lalu dikalikan 100\%. Hasil total padatan 
diperoleh dengan mengurangi angka 100\% dengan persentasi kadar air dari hasil pengujian (Yuksel, 2015).

Uji organoleptik dan mengetahui daya terima masyarakat terhadap velva kacang hijau rasa wortel. Pengujian hedonik dilakukan dengan cara sampel velva kacang hijau rasa wortel diletakkan pada cup dan disajikan, kemudian panelis membuat penilaian sampel yang diuji berdasarkan pada tingkat kesukaan terhadap sampel. Penilaian hedonik dilakukan oleh panelis agak terlatih sebanyak 30 orang, dengan memberikan penilaian meliputi tekstur, warna, rasa, dan aroma, serta overall kesukaan. Kategori hedonik/kesukaan yaitu mulai dari angka 1 (sangat tidak suka), 2 (tidak suka), 3 (suka), dan 4 (sangat suka) ((Tarwendah, 2017).

Uji kimiawi dilakukan untuk mengetahui kandungan serat kasar velva kacang hijau rasa wortel. Pengujian kadar serat kasar dilakukan dengan langkah, yaitu menyiapkan kertas saring dan cawan porselin yang sudah dikeringkan dengan oven selama 1 jam pada suhu $105^{\circ} \mathrm{C}$ serta sampel sejumlah 3 gram dimasukkan dalam labu erlenmeyer $300 \mathrm{ml}$ kemudian ditambah dengan $50 \mathrm{ml} \mathrm{H} 2 \mathrm{SO} 4$ 0,3 $\mathrm{N}$ lalu dididihkan selama 30 menit dan sesekali erlenmeyer digoyangkan. Selanjutnya sampel

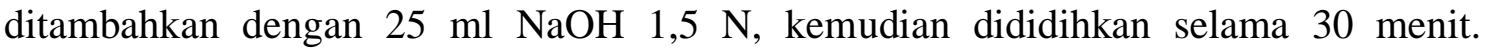
Suspensi disaring dengan kertas saring mengunakan buchner, dan kemudian dicuci berturut-turut dengan $50 \mathrm{ml}$ aquadest mendidih, $50 \mathrm{ml} \mathrm{H} 2 \mathrm{SO} 40,3 \mathrm{~N}, 50 \mathrm{ml}$ aquadest mendidih dan $25 \mathrm{ml}$ aceton. Kemudian kertas saring diangin-anginkan, lanjut dilipat dan dimasukkan dalam cawan porselin. Cawan porselin kemudian dikeringkan dengan oven selama \pm 6 jam pada suhu $105^{\circ} \mathrm{C}$. Setelah dikeringkan cawan porselin dimasukkan dalam desikator selama 15 menit kemudian ditimbang, Cawan porselin dimasukkan dalam furnace dan dipijarkan \pm 6 jam dalam suhu $400^{\circ}-600^{\circ} \mathrm{C}$. Setelah dipijarkan cawan porselin dimasukkan dalam desikator selama 15 menit, lanjut ditimbang kembali. Selanjutnya \% serat kasar dihitung dengan hasil pengurangan berat setelah pengovenan dikurangi berat setelah pemijaran, dikurangi berat kertas saring kosong, kemudian dibagi berat sampel dan dibuat persentase (AOAC, 2000).

Rancangan percobaan yang digunakan pada penelitian ini menggunakan Rancangan Acak Lengkap (RAL) faktor tunggal yaitu perlakuan substitusi wortel pada velva kacang hijau. Penelitian ini dilakukan dengan 5 perlakuan yaitu substitusi wortel 0\% (V0); 20\% (V1); 40\% (V2); 60\% (V3); dan 80\% (V4). dan setiap perlakuan dilakukan pengulangan sebanyak 3 kali sehingga terdapat 15 unit percobaan untuk diuji. Pembuatan velva kacang hijau rasa wortel diantaranya dilakukan dengan tiga tahap, yaitu pembuatan puree kacang hijau, puree wortel dan pembuatan velva.

Tahap pembuatan puree kacang hijau dilakukan dengan pemilihan kacang hijau dengan kriteria tanpa kulit, bersih berwarna putih kekuningan, baru dan tidak bulukan. Kacang hijau ditimbang dengan perbandingan 1 (kacang hijau/kg): 4 (air / volume) kemudian dilakukan blanching pada suhu $80^{\circ} \mathrm{C}$ selama 20 menit kemudian dihaluskan dengan menggunakan blender. Setelah dilakukan penghalusan dengan blender kemudian disaring. Puree kacang hijau lalu dipasteurisasi suhu $70^{\circ} \mathrm{C}$ selama 15 menit sambil diaduk kemudian puree kacang hijau didinginkan. 
Tahap pembuatan puree wortel, wortel disortasi, dibersihkan kemudian ditimbang sesuai ukuran, kemudian dipotong-potong ukuran dadu, untuk mempermudah penghalusan pada daging wortel, kemudian di-blanching dengaan perbandingan air 2:1 selama 3 menit, ditiriskan dan didinginkan pada sir es selama 5 menit, agar tekstur wortel tetap segar, kemudian ditiriskan kembali. Tujuan blanching untuk menghilangkan aroma langu pada wortel. Selanjutnya wortel yang telah didingin dibuat puree wortel, dengan cara diblander bersama air dengan perbandingan 2:1 selama \pm 3 menit dengan kecepatan sedang, hingga halus menyerupai bubur.

Taham pembuatan velva kacang hijau rasa wortel, dilakukan berdasarkan pada metode Rini \& Ishartani (2012), yang telah dimodifikasi yaitu puree kacang hijau disubstitusi dengan puree wortel sesuai dengan perlakuan, yaitu 0\%, 20\%, 40\%, 60\%, dan $80 \%$, ditambahkan madu $35 \%$ dari berat puree kemudian dihomogenisasi hingga menyatu. Setelah itu ditambahkan cmc sebanyak $0,75 \%$ dari total puree, kemudian diaduk dengan menggunakan mixer selama 5 menit, selanjutnya ditambahkan air jeruk lemon $0,1 \%$, garam $0,2 \%$ dari berat puree dan dihomogenisasi dengan mixer. Setelah itu adonan velva dilakukan aging selama 24 jam menggunakan refrigerator. Lalu velva dimasukkan ke dalam ice cream maker selama 30 menit. selanjutnya dilakukan hardening di dalam freezer selama 24 jam.

Pemakaian wortel pada velva dalam bentuk puree buah selain memberikan warna juga memberikan rasa pada velva kacang hijau. Sebagai sayuran yang berasal dari umbi, wortel juga mengandung pektin. Pektin merupakan serat alami yang bisa berfungsi sebagai penstabil dalam es krim. Untuk menambahkan rasa segar pada velva kacang hijau rasa wortel, maka ditambahkan air jeruk lemon (Ulya, Yunita, \& Haryani, 2019). Rasa manis pada velva kacang hijau rasa wortel, agar lebih rendah kalorinya, maka digunakan madu untuk pemanisnya.

\section{Hasil dan Pembahasan}

\section{A. Kajian Fisikokimia Velva Kacang Hijau Rasa Wortel}

Kajian fisik velva kacang hijau rasa wortel menjabarkan tentang hasil uji overrun, uji daya leleh, dan organoletik pada velva kacang hijau rasa wortel, dengan substitusi konsentrasi puree wortel yang berbeda dari 20\%, 40\%, 60\%, dan $80 \%$, dapat dicermati pada tabel 1 .

Tabel 1

Hasil Uji Analisis Overrun, Daya Leleh, Padatan, dan Serat Velva Kacang Hijau Rasa Wortel

\begin{tabular}{ccccc}
\hline Perlakuan & Overrun (\%) & Daya Leleh(Menit) & Total Padatan & Serat \\
\hline V0 & $19,42 \pm 0,32^{\mathrm{a}}$ & $18,53 \pm 0,32^{\mathrm{e}}$ & $29,94^{\mathrm{a}}$ & $7,21^{\mathrm{a}}$ \\
\hline V1 & $18,34 \pm 0,64^{\mathrm{b}}$ & $17,48 \pm 0,91^{\mathrm{d}}$ & $28,65^{\mathrm{b}}$ & $6,72^{\mathrm{b}}$ \\
\hline V2 & $17,16 \pm 0,72^{\mathrm{c}}$ & $16,56 \pm 0,13^{\mathrm{c}}$ & $27,23^{\mathrm{c}}$ & $5,53^{\mathrm{c}}$ \\
\hline V3 & $16,93 \pm 0,35^{\mathrm{d}}$ & $15,57 \pm 0,65^{\mathrm{b}}$ & $26,26^{\mathrm{d}}$ & $5,09^{\mathrm{c}}$ \\
\hline V4 & $15,17 \pm 0,66^{\mathrm{e}}$ & $13,84 \pm 0,95^{\mathrm{a}}$ & $25,17^{\mathrm{e}}$ & $4,61^{\mathrm{d}}$ \\
\hline
\end{tabular}

Sumber: Data Primer Penulis 2021 
Catatan: Data yang ditampilkan sebagai nilai rerata dari 3 ulangan, Superscript huruf yang berbeda pada baris yang sama menunjukkan perbedaan nyata $(\mathrm{P}<0,05), \mathrm{V} 0$, $\mathrm{V} 1$, V2, V3, dan V4 = Masing-masing konsentrasi puree wortel 0\%; 20\%; 40\%; $60 \%$; dan $80 \%$.

\section{B. Overrun}

Hasil pengukuran overrun pada tabel 1, menunjukkan bahwa substitusi puree wortel pada velva kacang hijau rasa wortel memberikan pengaruh nyata terhadap overrun $(\mathrm{P}<0,05)$, semakin tinggi konsentrasi substitusi wortel maka terjadi penurunan overrun, dan substitusi wortel lebih dari $80 \%$ memberikan penurunan tertinggi, berturut-turut dari V0. Hal ini disebabkan karena kemampuan mengikat air velva kacang hijau yang meningkat karena peningkatan substitusi puree wortel yang mengakibatkan campuran bahan velva kacang hijau rasa wortel semakin cepat mencair. Nilai onerrun dipengaruhi oleh tingkat kekentalan adonan, jika kekentalan adonan semakin tinggi maka tegangan permukaan adonan menjadi lebih tinggi yang mengakibatkan udara mudah menembus permukaan adonan sehingga velva akan lebih sulit untuk mengembang (Bahramparvar \& Tehrani, 2011).

Overrun yang dihasilkan velva kacang hijau rasa wortel memiliki nilai yang masih rendah dibanding overrun es krim, diketahui bahwa standar overrun es krim dan fruit ices berkisar antara 20-25\% (Frandsen and Arbuckle 1966) pada (Basito \& Meriza, 2018). Overrun velva kacang hijau rasa wortel yang rendah, dikarenakan absorbsi molekul protein yang rendah sehingga sulit mengalami penurunan tegangan permukaan sistem. Nilai overrun menunjukkan kemampuan adonan dalam pembuihan yang erat kaitannya dengan adanya penurunan tegangan permukaan pada sistem yang terdiri atas udara dan air, yang disebabkan oleh adanya absorbsi oleh molekul protein. Karena protein globular yang terutama sebagai penyusun protein nabati memberikan daya buih yang rendah karena sulit dalam mengurangi tegangan permukaan (Handayani, et al, 2014).

\section{Daya Leleh}

Hasil pengukuran daya leleh yang ditampilkan pada tabel 1, diketahui bahwa terdapat pengaruh nyata $(\mathrm{P}<0,05)$ dari substitusi wortel terhadap daya leleh velva kacang hijau rasa wortel. Artinya bahwa nilai rata-rata daya leleh velva kacang hijau rasa wortel yang dihasilkan dengan substitusi wortel 0\%-60\% memiliki nilai yang memenuhi kualitas daya leleh es krim sementara untuk perlakuan penambahan wortel $80 \%$ belum memenuhi kualitas daya leleh es krim. Standar daya leleh es krim yang baik berkisar antara 15- 25 menit (Yuksel, 2015). Berdasarkan kondisi fisik velva kacang hijau rasa wortel tersebut, diketahui bahwa konsentrasi substitusi puree wortel yang semakin banyak, akan menurunkan daya leleh velva kacang hijau sehingga kecepatan pelelehan semakin cepat (angka daya leleh semakin menurun).

Beberapa faktor yang mempengaruhi daya leleh diantaranya yaitu pembentukan kristal es, kekentalan produk, dan jumlah total padatan. Peningkatan daya leleh pelelehan pada pembuatan velva kacang hijau disebabkan karena pati 
kacang hijau dapat mencegah pembentukan kristal es yang besar pada velva. Pati kacang hijau dapat membantu sebagai bahan penstabil, yang memberikan tekstur velva menjadi seragam karena bersifat mengikat air. Hasil ekstraksi pati kacang hijau mempunyai kemurnian pati sangat tinggi (berkisar 99,22 - 99,80\%) dengan kadar abu dan lemak sangat rendah, dengan pemanasan sampai pada suhu $80^{\circ} \mathrm{C}$, maka akan terjadi proses gelatinisasi, sehingga dapat membantu menekan daya leleh velva kacang hijau rasa wortel.

Penambahan wortel membentuk kristal es yang kasar, dapat menurunkan daya tahan terhadap pelelehan dan sebaliknya jika kristal es yang terbentuk kecil akan lebih memperlambat proses pelelehan produk. Tingkat pelelehan produk frozen, yaitu tingkat kekentalan adonan yang akan membentuk kristal-kristal es. Kekentalan adonan dipengaruhi oleh komposisi velva, diantaranya kandungan pektin bahan utama dan bahan penstabil. Semakin kental adonan akan membentuk kristal es yang kecil sehingga memperlambat pelelehan produk, sebaliknya bila semakin cair adonan, maka kristal es yang terbentuk besar, sehingga akan mempercepat pelelehan (Frandsen \& Arbuckle, 1966).

Bahan penstabil velva kacang hijau rasa wortel ditambahkan sebanyak $0.75 \%$ (Ulya et al., 2019), digunakan untuk mengikat air dengan membentuk struktur gel yang memerangkap molekul-molekul air, sehingga menimbulkan peningkatan kekentalan adonan yang menyebabkan semakin sedikit rongga udara yang terbentuk dan resistensi pelelehan velva akan meningkat. Hal ini juga terjadi pada velva umbi bengkuang, bila rongga udara semakin banyak yang terbentuk, maka akan menyebabkan produk dessert frozen lebih cepat meleleh dan menyusut pada suhu ruang, karena rongga-rongga udara yang akan segera terlepas ketika meleleh (Failisnur, 2013).

\section{Kajian Total Padatan Kasar Kacang Hijau Rasa Wortel}

Hasil pengujian total padatan velva kacang hijau rasa wortel yang ditampilkan pada tabel 1, maka dapat diartikan bahwa bahwa terdapat pengaruh nyata $(\mathrm{P}<0,05)$ substitusi berbagai konsentrasi puree wortel terhadap total padatan velva kacang hijau rasa wortel. Dalam gambar 2 juga terlihat bahwa nilai rata-rata total padatan velva umbi kacang hijau rasa wortel kisaran antara $25,17 \%$ sampai $25,17 \%$. Total padatan pada velva kacang hijau rasa wortel pada pada penelitian ini telah memenuhi nilai kisaran total padatan untuk produk es krim. Standar padatan velva kacang hijau rasa wortel, menggunakan acuan standar padataan es krim yang baik, bahwa total padatan minimum untuk produk es krim yaitu sebaiknya tidak melebihi dari 40-42\% (Frandsen \& Arbuckle, 1966).

Sesuai dengan fenomena tersebut diketahui bahwa substitusi wortel akan meningkatkan total padatan velva kacang hijau rasa wortel. Total padatan dalam velva kacang hijau rasa wortel, diperoleh dari kacang hijau, wortel, madu, air jeruk lemon, garam dan bahan penstabil jenis cmc.

Peningkatan total padatan pada velva kacang hijau rasa wortel berhubungan dengan semakin sedikit jumlah air yang dibekukan karena nilai viskositas yang 
meningkat sehingga menurunkan titik bekunya. Semakin besar jumlah total padatan dalam produk beku, maka semakin rendah titik bekunya serta jumlah air yang dibekukan semakin kecil sehingga dapat mengurangi kristal es yang terbentuk (Frandsen \& Arbuckle, 1966).

Total padatan yang rendah akan menghasilkan tekstur yang kasar sedangkan total padatan yang terlalu tinggi akan mengakibatkan tekstur menjadi lembek dan lengket. Kecepatan pelelehan suatu produk frozen dessert tergantung pada total padatan yang terkandung pada produk. Produk yang mengandung total padatan tidak terlarut tinggi akan lebih lama meleleh.

\section{E. Kajian Kadar Serat Velva Kacang Hijau Rasa Wortel}

Kadar serat velva kacang hijau rasa wortel dari hasil pengujian yang tampilkan pada tabel 1, dapat dterjemahkan bahwa dengan substitusi puree wortel memiliki kecenderungan menurunkan nilai serat kasar velva kacang hijau rasa wortel. Hasil pengujian kadar serat kasar memperlihatkan bahwa substitusi wortel secara gradual memberikan kecenderungan penurunan serat kasar yang kecil yaitu 0,48 berdasarkan perhitungan diatas.

Substitusi wortel memiliki kecenderungan menurunkankan nilai kadar serat velva kacang hijau rasa wortel, yang disebabkan karena sifat dari wortel yang banyak mengandung air, dan lebih sedikit kandungan pektin dibandingkan kacang hijau. Pektin adalah senyawa polimer yang dapat mengikat air, membentuk gel, atau mengentalkan cairan (Sulihono, et al 2012). Pektin yang terkandung didalam wortel dan kacang hijau bereaksi dengan asam maka akan mengental (Permatasari, 2012).

Penyumbang serat pada velva kacang hijau wortel, selain serat dari bahan utama velva, juga dipengaruhi oleh penambahan bahan penstabil yang digunakan yaitu cmc. Penambahan penstabil yang berupa cmc pada velva dengan konsentrasi $0,75 \%$, dapat meningkatkan nilai kadar serat kasar, karena mampu mengikat komponen di dalam bahan sehingga serat kasar tetap dipertahankan. Serat kasar yang dihasilkan velva kacang hijau rasa wortel mulai dari 6, $72 \%-4,61 \%$. Angka tersebut dapat membantu memberikan asupan serat untuk tubuh, karena batasan pemberian serat maksimal yang boleh dikonsumsi adalah 20- 35 gr/hari, dengan anjuran kacang - kacangan, buah dan sayuran (Perkeni, 2021).

\section{F. Kajian Organoleptik Velva Kacang Hijau Rasa Wortel}

Kajian organoleptik velva kacang hijau rasa wortel menjabarkan tentang karakteristik, dengan indikator tekstur, warna, rasa dan aroma pada velva kacang hijau rasa wortel, dengan substitusi konsentrasi puree wortel yang berbeda dari $20 \%$, $40 \%, 60 \%$, dan $80 \%$, dapat dicermati pada tabel 2 . 
Tabel 2

Hasil Uji Organoleptik Velva Kacang Hijau Rasa Wortel

\begin{tabular}{|c|c|c|c|c|}
\hline \multirow{2}{*}{ Perlakuan } & \multicolumn{4}{|c|}{ Uji Organoleptik } \\
\hline & Tekstur & Warna & Rasa & Aroma \\
\hline V0 & $\begin{array}{l}\text { Padat, lembut, namun } \\
\text { sedikit berbutir }\end{array}$ & $\begin{array}{l}\text { Putih kekuningan } \\
\text { yang cerah }\end{array}$ & Manis & Kacang hijau \\
\hline V1 & $\begin{array}{l}\text { Padat dan kristal } \\
\text { lembut }\end{array}$ & $\begin{array}{l}\text { Putih keoranyean dan } \\
\text { menarik }\end{array}$ & $\begin{array}{l}\text { Manis sedikit } \\
\text { asam }\end{array}$ & $\begin{array}{l}\text { Masih dominan } \\
\text { kacang hijau }\end{array}$ \\
\hline V2 & $\begin{array}{l}\text { Padat dan kristal agak } \\
\text { lembut }\end{array}$ & $\begin{array}{l}\begin{array}{l}\text { Oranye muda } \\
\text { menarik }\end{array} \\
\end{array}$ & $\begin{array}{l}\text { Manis sedikit } \\
\text { asam }\end{array}$ & $\begin{array}{l}\text { Perpaduan } \\
\text { hijau wortel }\end{array}$ \\
\hline V3 & $\begin{array}{l}\text { Padat dan kristal agak } \\
\text { kasar }\end{array}$ & $\begin{array}{lll}\begin{array}{l}\text { Oranye } \\
\text { menarik }\end{array} & \text { cerah } & \text { dan } \\
\end{array}$ & $\begin{array}{l}\text { Manis sedikit } \\
\text { asam }\end{array}$ & $\begin{array}{l}\text { Wortel } \\
\text { dominan }\end{array}$ \\
\hline V4 & $\begin{array}{lll}\text { Padat } & \text { dan } & \text { kristal } \\
\text { kasar } & & \end{array}$ & $\begin{array}{l}\text { Oranye cukup tua } \\
\text { namun masih menarik }\end{array}$ & $\begin{array}{l}\text { Manis sedikit } \\
\text { asam }\end{array}$ & Dominan Wortel kuat \\
\hline
\end{tabular}

Sumber: Data Primer Penulis 2021

Catatan: Data yang ditampilkan sebagai nilai rerata dari 3 ulangan, Superscript huruf yang berbeda pada baris yang sama menunjukkan perbedaan nyata $(\mathrm{P}<0,05), \mathrm{V} 0$, $\mathrm{V} 1, \mathrm{~V} 2, \mathrm{~V} 3$, dan V4 = Masing-masing konsentrasi puree wortel 0\%; 20\%; 40\%; $60 \%$; dan $80 \%$.

Tampilan velva kacang hijau rasa wortel dengan substitusi konsentrasi puree wortel yang berbeda dari 20\%, 40\%,60\%, dan $80 \%$, dapat dicermati pada gambar 1 berikut.

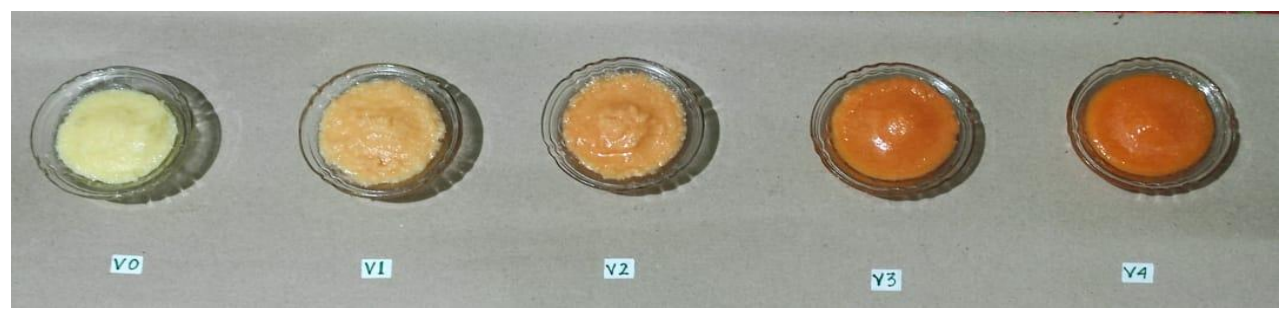

\section{Gambar 1}

Velva Kacang Hijau Wortel Dengan Masing-Masing Konsentrasi Puree Wortel 0\%(V0); 20\%(V1); 40\%(V2); 60\%(V3); Dan 80\%(V4)

Sumber: Triastuti (2021)

Kajian hedonik velva kacang hijau rasa wortel menjabarkan tentang hasil pengujian penerimaan masyarakat, dengan menilai tekstur, warna, rasa dan aroma serta overall pada velva kacang hijau rasa wortel, dapat dicermati pada tabel 3. 


\section{Tabel 3}

Hasil Uji Hedonik Velva Kacang Hijau Rasa Wortel

\begin{tabular}{lccccl}
\hline \multirow{2}{*}{ Perlakuan } & \multicolumn{5}{c}{ Uji Hedonik } \\
\cline { 2 - 6 } & Tekstur & Warna & Rasa & Aroma & Overall Kesukaan \\
\hline V0 & $2,44 \pm 1,04^{\mathrm{a}}$ & $3,12 \pm 0,78$ & $2,81 \pm 0,97$ & $2,80 \pm 0,82$ & $2,72 \pm 1,02$ \\
\hline V1 & $3,14 \pm 0,41^{\mathrm{b}}$ & $3,21 \pm 0,44$ & $2,92 \pm 0,49$ & $3,08 \pm 0,70$ & $3,12 \pm 0,60$ \\
\hline V2 & $3,34 \pm 1,05^{\mathrm{b}}$ & $3,24 \pm 0,68$ & $3,12 \pm 0,72$ & $2,96 \pm 0,68$ & $3,08 \pm 0,76$ \\
\hline V3 & $3,78 \pm 0,69^{\mathrm{b}}$ & $3,32 \pm 0,48$ & $3,88 \pm 0,60$ & $3,16 \pm 0,68$ & $3,36 \pm 0,62$ \\
\hline V4 & $2,98 \pm 0,66^{\mathrm{a}}$ & $3,24 \pm 0,52$ & $2,72 \pm 0,79$ & $2,68 \pm 0,75$ & $2,96 \pm 0,54$ \\
\hline
\end{tabular}

Sumber: Data Primer Penulis 2021

Catatan: Data yang ditampilkan sebagai nilai rerata dari 3 ulangan, Superscript huruf yang berbeda pada baris yang sama menunjukkan perbedaan nyata $(\mathrm{P}<0,05), \mathrm{V} 0$, V1, V2, V3, dan V4 = Masing-masing konsentrasi puree wortel 0\%; 20\%; 40\%; $60 \%$; dan $80 \%$. Kategori hedonik/kesukaan yaitu mulai dari angka 1 (sangat tidak suka), 2 (tidak suka), 3 (suka), dan 4 (sangat suka).

Hasil pengujian statistik uji organoleptik terhadap tekstur, rasa, warna, dan aroma, serta overall kesukaan velva kacang hijau rasa wortel, dengan konsentrasi wortel yang berbeda dapat dicermati pada tabel 3. Data tersebut dapat dijelaskan bahwa velva kacang hijau rasa wortel, dengan konsentrasi yang berbeda menunjukkan tidak adanya perbedaan yang nyata $(\mathrm{P}>0,05)$ terhadap parameter warna, rasa, aroma, dan overall kesukaan, namun terdapat perbedaan yang nyata $(\mathrm{P}<0,05)$.

\section{G. Tekstur}

Tekstur velva kacang hijau rasa wortel untuk penilaian tekstur velva kacang hijau rasa wortel, berdasarkan Tabel 3. diatas dapat diketahui bahwa peningkatan substitusi wortel lebih dari $60 \%$ menurunkan rata-rata penilaian panelis terhadap tekstur velva kacang hijau rasa wortel. Berdasarkan penilaian panelis penurunan nilai kesukaan tekstur velva disebabkan karena velva memiliki tekstur yang terlalu kental dan agak keras. Penambahan wortel dengan taraf konsentrasi 20\%-60\% memberikan interpretasi suka dari panelis terhadap tekstur velva kacang hijau.

Berdasarkan penilaian panelis tekstur velva yang dihasilkan dari penambahan tersebut memberikan kesan tekstur cukup lembut. Tekstur velva kacang hijau yang lembut dihasilkan akibat kandungan pektin yang terdapat pada kacang hijau sendiri dan wortel. Pektin pada produk velva juaga bisa berfungsi sebagai bahan penstabil. Fungsi penstabil di dalam velva untuk membrikan tekstur yang lembut, karena dapat mengikat air yang ada pada velva. Meskipun kedua bahan baik kacang hijau maupun wortel mengandung pektin, untuk meningkatkan kualitas kelembutan tekstur pada velva kacang hijau rasa wortel, ditambahkan $\mathrm{cmc}$. Pemakaian cmc juga dapat meningkatkan nilai dari serat kasar velva kacang hijau rasa wortel, seperti halnya pada penelitian terdahulu dalam pembuatan velva wortel dengan viarietas dari daerah berbeda dan pemakaian beberapa jenis bahan penstabil yang berbeda 
(Rini \& Ishartani, 2012). Cmc yang ditambahkan pada velva kacang hijau rasa vortel menggunakan konsentari $0,75 \%$ pada pada semua perlakuan, dengan tujuan untuk membantu membentuk kristal es yang kecil dan seragam, sehingga velva bertekstur lembut.

\section{H. Warna}

Warna velva kacang hijau rasa wortel untuk penilaian warna velva kacang hijau rasa wortel. Pernyataan ini disebabkan oleh jumlah substitusi wortel yang digunakan, berdampak pada warna. Berdasarkan tabel 3 diatas dapat diketahui bahwa peningkatan substitusi wortel lebih dari $20 \%$ meningkatkan rata-rata penilaian panelis terhadap warna velva kacang hijau rasa wortel.

Berdasarkan penilaian panelis peningkatan nilai kesukaan warna velva disebabkan karena velva memiliki warna yang lebih kuat dan menarik. Penambahan wortel dengan taraf konsentrasi 20\%-80\% memberikan interpretasi suka dari panelis terhadap warna velva kacang hijau. Berdasarkan penilaian panelis warna velva yang dihasilkan dari penambahan tersebut memberikan kesan warna menarik. Warna velva kacang hijau yang menarik, dihasilkan akibat kandungan betakarotin yang terdapat pada wortel, dan pengupasan kulit kacang hijau, sehingga menghasilkan warna yang menarik, yaitu oranye yang cerah. Betakarotin yang ada pada wortel memberikan zat warna yang alami, dan lebih cerah bila dalam pemakaiannya dipanaskan pada suhu $80^{\circ} \mathrm{C}$ (Trianto, 2014).

\section{Rasa}

Rasa yang dihasilkan pada velva kacang hijau rasa wortel dipengaruhi oleh bahan yang terdiri dari kacang hijau, wortel, madu, air dan kulit jeruk lemon, cmc dan garam. Peningkatan substitusi wortel lebih dari $20 \%$ meningkatkan rata-rata penilaian panelis terhadap rasa velva kacang hijau rasa wortel. Berdasarkan penilaian panelis peningkatan nilai kesukaan tekstur velva kacang hijau rasa wortel, disebabkan karena velva kacang hijau rasa wortel memiliki rasa yang semakin kuat. Penambahan wortel dengan taraf konsentrasi 20\%-80\% memberikan interpretasi suka dari panelis terhadap rasa velva kacang hijau rasa wortel.

Berdasarkan penilaian panelis rasa velva kacang hijau rasa wortel yang dihasilkan dari penambahan sebanyak $60 \%$, memberikan kesan rasa yang baik, karena masing-masing bahan tidak saling mendominasi. Selain juga terdapat rasa kesan segar yang dipengaruhi oleh penggunaan air jeruk lemon (Ulya et al., 2019), sehingga berefek segar dan mengurangi rasa langu pada wortel dan kacang hijau.

\section{J. Aroma}

Aroma velva kacang hijau rasa wortel untuk hasil penilaian yang disajikan pada tabel 3, diketahui bahwa peningkatan substitusi puree wortel lebih dari $20 \%$ menurunkan rata-rata penilaian panelis terhadap aroma velva kacang hijau rasa wortel. Berdasarkan penilaian panelis penurunan nilai kesukaan aroma velva disebabkan karena wortel memiliki aroma langu, yang desebabkan oleh kandungan Isocoumarin pada wortel (Dalimartha \& Rohmawati, 2005). 
Penambahan wortel dengan taraf konsentrasi 20\%-80\% memberikan interpretasi suka dari panelis terhadap aroma velva kacang hijau rasa wortel. Berdasarkan penilaian panelis aroma velva yang dihasilkan dari penambahan $60 \%$ tersebut memberikan kesan aroma wortel yang baik, tidak terlalu dominan. Aroma khas wortel yang lagu juga tersamarkan oleh penggunaan kulit jeruk lemon yang halus. Aroma velva kacang hijau rasa wortel yang wangi, karena kandungan sitrus pada kulit jeruk lemon, yang memberikan efek aroma segar. Aroma velva kacang hijau rasa wortel menjadi lebih segar, sehingga velva diterima konsumen dengan baik.

\section{K. Overall}

Overall velva kacang hijau rasa wortel penilaian yang diberikan panelis, seperti yang ditampilkan pada tabel 4 diatas, dapat diketahui bahwa peningkatan substitusi wortel lebih dari $20 \%$ menurunkan rata-rata penilaian panelis terhadap overall velva kacang hijau rasa wortel. Berdasarkan penilaian panelis penurunan nilai kesukaan overall velva disebabkan karena velva memiliki overall yang terlalu kental dan agak keras. Penambahan wortel dengan taraf konsentrasi 20\%-80\% memberikan interpretasi suka dari panelis terhadap overall velva kacang hijau. Berdasarkan penilaian panelis overall velva yang dihasilkan dari penambahan tersebut memberikan kesan overall cukup lembut. Overall velva kacang hijau yang lembut dihasilkan akibat kandungan pektin yang terdapat pada kacang hijau sendiri dan wortel. Pektin pada produk velva juaga bisa berfungsi sebagai bahan penstabil.

Hal ini menyatakan, bahwa semakin tinggi konsentrasi substitusi wortel, menunjukkan semakin kasar tekstur velva kacang hijau rasa wortel, namun jika penambahannya berlebihan maka velva yang dihasilkan lebih cair, sehingga panelis menilai tingkat kesukaannya menurun dan tekstur velva yang baik adalah halus/ lembut, tidak keras, dan mengkilap. Tujuan utama dalam pemakaian wortel, pada produk frozen dessert yaitu untuk menghasilkan warna, rasa, tekstur dan aroma yang baik, untuk menghambat atau mengurangi pembentukan kembali kristal es krim selama penyimpanan dan menghasilkan keseragaman tekstur produk.

\section{Kesimpulan}

Berdasarkan hasil penelitian dapat disimpulkan bahwa penambahan berbagai konsentrasi wortel pada velva kacang hijau memberikan pengaruh nyata pada overrun, daya leleh dan total padatan serta serat. Semakin tinggi penambahan konsentrasi wortel maka semakin menurunkan overrun, menurunkan daya leleh dan total padatan, pada velva kacang hijau rasa wortel, serta memiliki kecenderungan penurunanan nilai kadar serat velva kacang hijau rasa wortel

Penilaian hedonik semakin tinggi penambahan wortel pada velva kacang hijau akan menghasilkan tekstur yang tidak terlalu kental dan agak keras sehingga panelis tidak menyukainya. Perlakuan penambahan wortel pada velva kacang hiaju yang optimal yaitu sebesar $60 \%$ karena menghasilkan overrun sebesar 16,93\%; daya leleh yang memenuhi kualitas mutu yaitu 15,57 menit, total padatan yang memenuhi standar 
sebesar 26,26\%; serta menghasilkan karakteristik hedonik yang dapat diterima dengan baik oleh konsumen.

Pada penelitian selanjutnya dapat dilakukan pengamatan pada kandungan nutrisi yang lebih lengkap seperti lemak, vitamin A, pretein, dan masa simpan pada velva kacang hijau rasa wortel.

\section{BIBLIOGRAFI}

AOAC. (2000). Official Methods of Analysis of the Association of Official Analysis Chemists. (17th editi). Washington. D.C.: The Scientific Association Dedicated to Analytical Excellence. Google Scholar

Azlan, Izma Izzaty Binti. (2018). Khasiat Wortel (Daucus Carota) Dalam Mengurangi Hepatotoksisitas Pada Mencit (Mus-Musculus) Yang Diinduksi Monosodium Glutamat (Msg). Program Studi Pendidikan Dokter Fakultas Kedokteran Universitas Sumatera Utara Medan, 17. Retrieved From Https://Repositori.Usu.Ac.Id/Bitstream/Handle/123456789/13684/150100198.pdf? sequence $=1 \&$ isAllowed $=\mathrm{y}$

Bahramparvar, M., \& Tehrani, M. M. (2011). Application and Functions of Stabilizers in Ice Cream. Food Reviews International, 27, 37-41. Retrieved from Google Scholar

Basito, Bara Yudhistira, \& Meriza, Dara Audina. (2018). Kajian Penggunaan Bahan Penstabil Cmc (Carboxil Methyl Cellulosa) Dan Karagenan Dalam Pembuatan Velva Buah Naga Super Merah (Hylocereus Costaricensis). Jurusan Teknologi Dan Industri Pertanian Indonesia, 10(01), 42-49. Google Scholar

Dalimartha, Setiawan, \& Rohmawati, Tety. (2005). Atlas Tumbuhan Obat Indonesia. (Jilid 3). Retrieved from http://kin.perpusnas.go.id/DisplayData.aspx $?$ pId=206027\&pRegionCode=UN11M AR\&pClientId=112 Google Scholar

Failisnur, Failisnur. (2013). Karakteristik Es Krim Bengkuang Dengan Menggunakan Beberapa Jenis Susu. Jurnal Litbang Industri, 3(1), 11. Google Scholar

Frandsen, J. H., \& Arbuckle, W. S. (1966). Ice cream and Related Products. Conecticut.: The AVI Publishing Company, Inc. Westport,. Google Scholar

Goff, H. Douglas, \& Hartel, Richard W. (2013). Ice Cream (Seventh Ed). Google Scholar

Goff, H. Douglas, \& P, Spagnuolo. (2001). Effect of stabilizers on fat destabilization measurement in ice cream. Milchwissenschaft, 56, 450-453. Google Scholar

Handayani, N., Sulistyowati, M., \& Sumarmono, J. (2014). Overrun, Waktu Leleh dan Kesukaan Es Krim Yoghurt Susu Sapi dengan Persentase Gula yang Berbeda. 
Tri Rettagung Diana, U. Yuyun Triastuti, Denta Nabila Rizki

Jurnal Fakultas Peternakan. Unsoed, Purwokerto. Google Scholar

Hayashi, K., Hara, H., Asvarujanon, P., Aoyama, Y., \& Luangpituksa, P. (2001). Ingestion Od insoluble dietary fiber increased zinc And iron absorbsion and restored growth rate and zinc absorbtion suppressed by dietary in rats. British Journal of Nutrition, 86(4), 443-451. Google Scholar

Mustakim, M. (2014). Budidaya Kacang Hijau Secara Intensif. Yogyakarta: Pustaka Baru Press. Google Scholar

Perkeni. (2021). Pedoman Pengelolaan dan Pencegahan Diabetes Melitus Tipe 2 Dewasa di Indonesia. In Global Initiative for Asthma. Retrieved from www.ginasthma.org. Google Scholar

Permatasari, Tasia Galuh. (2012). Praktek Produksi Proses Pembuatan Selai Wortel. Tugas Akhir. Disusun Oleh: Tasia Galuh Permatasari H 3109056 Program Diploma Iii Teknologi Hasil Pertanian Fakultas Pertanian Universitas Sebelas Maret Surakarta. Google Scholar

Priyanto, Triwitono, Yustinus, Marsono, Agnes, Murdiati, \& Djagal Wiseso, Marseno. (2017). Isolasi dan Karakterisasi Sifat Pati Kacang Hijau (Vigna radiata L.) Beberapa Varietas Lokal Indonesia. AGRITECH, Vol. 37(No. 2), 192-198. Google Scholar

Rini, Ayu Kusuma, \& Ishartani, Dwi. (2012). Pengaruh kombinasi bahan penstabil CMC dan gum arab terhadap mutu velva wortel ( Daucus Carota L .) varietas selo dan varietas tawangmangu. Jurnal Teknosains Pangan, 1(1), 86-94. Google Scholar

Silva, Anggun Nurul, Alamsyah, Ahmad, \& Saloko, Satrijo. (2018). Pengaruh Jenis Dan Konsentrasi Bahan Penstabil Terhadap Mutu Velva Labu Kuning (Cucurbita Moschata). Fakultas Teknologi Pangan Dan Agroindustri Universitas Mataram, $0-16$.

Sulihono, Andreas, Tarihoran, Benyamin, \& Agustina, Tuti Emilia. (2012). Jenis Pelarut Terhadap Ekstraksi Pektin Dari Kulit Jeruk Bali ( Citrus Maxima ). Jurnal Teknik Kimia, 18(4), 1-8. Google Scholar

Tarwendah, Ivani Putri. (2017). Jurnal Review: Studi Komparasi Atribut Sensoris Dan Kesadaran Merek Produk Pangan. Jurnal Pangan Dan Agroindustri, 5(2), 66-73. Google Scholar

Trianto, Sabda Suryawan. (2014). Ekstraksi Zat Warna Alami Wortel (Daucus Carota)Menggunakan Pelarut Air. Ekuilibium, 13(2), 51-54. Google Scholar

Ulya, Rahmatul, Yunita, Dewi, \& Haryani, Sri. (2019). Pembuatan Velva Wortel (Daucus Carota L.) - Jeruk (Citrus Sinensis) Dengan Variasi Jenis Penstabil (CMC, Karagenan Dan Gelatin). Jurnal Ilmiah Mahasiswa Pertanian, 4(3), 47-54. Google 
Scholar

Utafiyani, Yusasrini, Ni Luh Ari, \& I Gusti Ayu Ekawati. (2018). Pengaruh Perbandingan Tepung Kacang Hijau (Vigna Radiata) Dan Terigu Terhadap Karakteristik Bakso Analog. Jurnal Ilmu Dan Teknologi Pangan (ITEPA), 7(1), 12.

Yuksel, Arzu Kavaz. (2015). The Effects of Blackthorn (Prunus Spinosa L.) Addition on Certain Quality Characteristics of Ice Cream. Journal Of Food Quality, 38 No.6, 413-421. Retrieved from https://pubag.nal.usda.gov/?f\%5Bjournal_name\%5D\%5B\%5D=Journal+of+food+ quality\&f\%5Bpublication_year_rev $\% 5 \mathrm{D} \% 5 \mathrm{~B} \% 5 \mathrm{D}=7985$ -

2015\&f\%5Bsource\%5D\%5B\%5D=2015+v.38+no.6 Google Scholar

Zurriyati, Yayu, \& Dahono. (2016). Keragaman Sumber Daya Genetik Tanaman Buahbuahan Eksotik di Kabupaten Bintan , Provinsi Kepulauan Riau. Buletin Plasma Nutfah, 22(1), 11-20. Google Scholar

\section{Copyright holder:}

Tri Rettagung Diana, U. Yuyun Triastuti, Denta Nabila Rizki (2022)

First publication right:

Syntax Literate: Jurnal Ilmiah Indonesia

This article is licensed under:

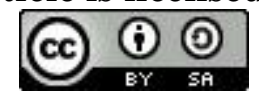

